\title{
Head and Neck Lymphomas: Tip of the Iceberg?
}

\section{Suresh Babu M.C. 1, Govind Babu.K1, Lakshmaiah KC1, Lokanatha D1, Premalatha C.S. 2, Suma MN², Rajeev LK', Linu Jacob Abraham ${ }^{1}$, Lokesh KN ${ }^{1}$, Rudresha AH ${ }^{1}$, Sunny Garg ${ }^{1}$, Vishwanath Sathyanarayanan ${ }^{1}$}

\author{
${ }^{1}$ Department of Medical Oncology, Kidwai Memorial Institute, India \\ ${ }^{2}$ Department of Pathology, Kidwai Memorial Institute, of Oncology, Bangalore, Karnataka, India
}

\begin{abstract}
Background: Lymphomas comprise around 5\% of all head and neck neoplasms and is the second most common extra nodal non hodgkin's lymphoma (NHL). However there is sporadic data on this entity from the subcontinent and hence we undertook this study.
\end{abstract}

Methodology: This retrospective observational study was conducted at a tertiary care oncology center in India on diagnosed cases of NHL between January 2007 and December 2013. All patients were diagnosed based on histopathology and immunohistochemistry. Staging work up was done in all patients. Patients were considered as primary Head and Neck lymphomas if there was head and neck as the predominant site with or without regional lymph node involvement.

Results: A total of 39 patients were studied. The age at presentation ranged from 29 to 78 years. The most common site of presentation was oral cavity $(26 \% ; \mathrm{n}=10)$, followed by parotid and thyroid (18\% each; $\mathrm{n}=7)$, eye $(12 \%, \mathrm{n}=5)$, maxilla $(8 \% ; n=3)$, paranasal sinuses $(8 \% ; n-=3)$ cheek $(8 \%, n=3)$, and nasal cavity $(2 \%, n=1) .41 \%(n=16)$ cases were in stage I, $43 \%(n=17)$ in stage II, 3\% $(n=1)$ in stage III, and $13 \%(n=5)$ were in stage IV. Most common histology was DLBCL $(71 \% ; n=28)$, followed by plasmablastic $(10 \% ; n=4)$, marginal zone $(8 \%, n=3)$, mantle cell $(3 \% ; n=1)$, follicular lymphomas $(5 \% ; n=2)$, and NK/T cell lymphoma $(3 \% ; n=1)$. Most of the patients were of low risk $(67 \% ; n=26)$, followed by intermediate $(23 \% ; n=9)$, and high risk $(10 \% ; n=4)$. Patients were treated with anthracycline based chemotherapy $+/$ - radiotherapy. In this study, stage I and stage II patients had a better prognosis and overall survival, median OS 28 months and 11 months, respectively. In stage III and IV, it was 7 and 3 months, respectively. According to site, the best median overall survival was seen with parotid $(27 \mathrm{~m})$, paranasal sinus $(26 \mathrm{~m})$, and oral cavity $(23 \mathrm{~m})$, followed by thyroid $(18 \mathrm{~m})$ nasal cavity $(17 \mathrm{~m})$, maxilla $(11 \mathrm{~m})$, eye $(8 \mathrm{~m})$, and cheek $(7 \mathrm{~m})$.

Conclusions: Head and neck lymphoma is probably the tip of the iceberg and is an undereported entity.

\section{INTRODUCTION}

Of all the head and neck neoplasms, malignant lymphomas represent approximately $5 \%{ }^{1}$. With increasing life expectancy ${ }^{2}$, improved AIDS survivorship, and increasing organ transplantation, it's frequency is increasing. For this reason, AIDS should be excluded in the diagnosis of extranodal $\mathrm{NHL}^{3}$. It carries a poor prognosis and presents with a disseminated disease at the time of presentation ${ }^{2}$.

Head and neck is a common site for non-Hodgkin's lymphomas, being second most common extranodal site after gastrointestinal tract. ${ }^{4}$. They comprise of the $10-20 \%$ cases of all lymphomas. Mostly, they are of
B-cell origin, T-cell lymphomas being usually restricted to nasal cavity or nasopharyn $x^{5}$.

The presentation is usually submucosal, rather than ulcerative, commonly seen in squamous cell carcinoma ${ }^{6}$. Oral lymphomas present as an ulcerated or nodular growth on tongue, gingival, or palate. It is common in HIV positive patients.It may present either as a tumour or an ulcerated lesion, most commonly on the gingivae, tongue, or palate $\mathrm{p}^{7,8}$. Underlying bone infiltration and destruction may be seen with mature B-NHL, which are one of the most rapidly growing tumor types ${ }^{9,10}$.

This article is published under the terms of the Creative Commons Attribution License 4.0

Author(s) retain the copyright of this article. Publication rights with Alkhaer Publications.

Published at: http://www.ijsciences.com/pub/issue/2015-07/

Article Number: V4201506737; Online ISSN: 2305-3925; Print ISSN: 2410-4477 
Salivary glands comprise for 2-5\% of lymphomas, most frequently parotid gland. Most common histologies are marginal-zone B-cell lymphoma (MALT), follicular lymphoma, and diffuse large Bcell lymphomas(DLBCL) ${ }^{11}$. Sjogren's syndrome might be associated ${ }^{12}$ and facial paresis is rarely seen.

Thyroid lymphoma presents as a rapidly enlarging neck mass, causing hoarseness and dysphagia. It is associated with Hashimoto's syndrome in $80 \%$ of the cases. Most frequent forms are MALT and DLBCL ${ }^{13}$.

Nasal lymphoma is a rare entity, usually associated with EBV infection. It is known by various names, like lethal midline granuloma, pseudolymphoma, and polymorphic reticulosis. ${ }^{14}$ It causes soft tissue destruction with extensive local spread to paranasal sinuses, hard palate, cheek, alveolar bone, nasopharynx, orbit, or intracranial cavity. The prognosis is poor with a high rate of mortality ${ }^{15}$.

Paranasal sinus lymphoma usually extends into the orbit, causing exophthalmos and diplopia. DLBCL is the most common histology ${ }^{15}$. DLBCL is the most common pathological form.

\section{METHODOLOGY}

This was a retrospective observational study done at Kidwai Memorial Institute of Oncology, Bengaluru a tertiary care centre in Southern India. All consecutive cases aged 15 years or more, diagnosed as Head and Neck Lymphoma (extra nodal) by tissue biopsy, confirmed by immunohistochemistry (WHO classification) between January 2007 and December 2013 were included in the study. This study study describes the clinic-pathologic characteristics of 39 patients with head and neck lymphomas, who presented to Kidwai Memorial Institute of Oncology, Bangalore. The informed consent was taken from all the patients and demographic details, clinical details, investigations and treatment details were recorded and analysed.

Evaluation included patient history and physical examination; complete hemogram and serum biochemistry, including LDH; HIV, HBS-Ag and echocardiography or MUGA scan. Computed tomography (CT) scan of chest, abdomen, and pelvis in affordable and chest X-ray/ultrasound abdomen/pelvis in not affordable patients; bone marrow biopsy from iliac crest. Cerebrospinal fluid (CSF) analysis was done in all cases. Patients were staged according to Ann-Arbor staging as modified by Cotswold's and International prognostic scoring (IPI) was done. All patients either underwent open biopsy/ superficial parotidectomy/ total parotidectomy for diagnosis. They all received either combination of rituximab $375 \mathrm{mg} / \mathrm{m}^{2}$, cyclophosphamide $750 \mathrm{mg} / \mathrm{m}^{2}$, Adriamycin $50 \mathrm{mg} / \mathrm{m}^{2}$, vincristine $1.4 \mathrm{mg} / \mathrm{m}^{2}$ and prednisolone $100 \mathrm{mg} / \mathrm{d}$ for 5 days R-CHOP or CHOP or COP. Radiotherapy was given in 2 patients at a dose of $40 \mathrm{~Gy}$. The responses were assessed according to standard criteria. The patients were treated as per the institute protocol. The clinico-pathological factors were statistically evaluated for poor survival.

\section{DEFINITIONS}

Primary extra nodal head and neck lymphoma was defined as involvement of head and neck with no or minor lymph node involvement while extensive involvement is defined as the involvement of both EN and nodal sites.

\section{STATISTICAL ANALYSIS}

Calculation of median and range was done using Microsoft excel, and overall survival was calculated from diagnosis to the last follow up or death due to any cause.

\section{RESULTS}

Table 1 depicts the baseline characteristics of the patients and distribution based on the site, age, stage IPI risk, histology and median overall survival (OS) based on site of disease. Table 2 depicts the treatment modality used and survival according to stage of disease. Table 3 represents comparison of our study with others.

\section{Site}

The most common site of presentation was oral cavity $(26 \% ; n=10)$, followed by parotid and thyroid $(18 \%$ each; $n=7)$, eye $(12 \%, n=5)$, maxilla $(8 \% ; n=3)$, paranasal sinuses $(8 \% ; n-=3)$ cheek $(8 \%, n=3)$, and nasal cavity $(2 \%, \mathrm{n}=1)$. (Table 1$)$

\section{Stage}

$41 \%(n=16)$ cases were in stage I, $43 \%(n=17)$ in stage II, $3 \%(\mathrm{n}=1)$ in stage III, and $13 \%(\mathrm{n}=5)$ were in stage IV. (Table 1)

\section{Histology}

Most common histology was DLBCL (71\%; $n=28)$, followed by plasmablastic $(10 \% ; n=4)$, marginal zone $(8 \%, n=3)$, mantle cell $(3 \% ; n=1)$, follicular lymphomas $(5 \% ; \mathrm{n}=2)$, and $\mathrm{NK} / \mathrm{T}$ cell lymphoma $(3 \% ; n=1)$. (Table 1)

\section{IPI risk}

Most of the patients were of low risk $(67 \%$; $n=26)$, followed by intermediate $(23 \% ; n=9)$, and high risk $(10 \% ; \mathrm{n}=4)$. (Table 1$)$

\section{Treatment}

Chemotherapy alone was given in $36 \%(n=14)$ of the patients, and chemotherapy along with radiotherapy in $51 \%(\mathrm{n}=20)$ of the patients. Remaining patients were either lost to follow up or untreated. Most of the early stage patients were treated with both the modalities of treatment. (Table 2)

\section{Survival}


In this study, stage I and stage II patients had a better prognosis and overall survival, median OS 28 months and 11 months, respectively. In stage III and IV, it was 7 and 3 months, respectively. According to site, the best median overall survival was seen with parotid $(27 \mathrm{~m})$, paranasal sinus $(26 \mathrm{~m})$, and oral cavity $(23 \mathrm{~m})$, followed by thyroid $(18 \mathrm{~m})$ nasal cavity $(17$ $\mathrm{m})$, maxilla $(11 \mathrm{~m})$, eye $(8 \mathrm{~m})$, and cheek $(7 \mathrm{~m})$. (Table 1 and 2)

\section{DISCUSSION}

Consideration of a lymphoma as primary nodal or EN is controversial and hence two schools of thought have evolved to define this entity. According to some authors, primary EN-NHL is defined as involvement of other organs with no or minor lymph node involvement while extensive involvement is defined as the involvement of both EN and nodal sites. Few other suggest that involvement of an EN site with or without regional lymph node involvement is primary EN-NHL.

In this study, we have retrospectively analysed the clinico-pathologic characteristics of 39 patients with head and neck lymphomas, who presented to Kidwai Memorial Institute of Oncology, Bangalore.

The age at presentation ranged from 29 to 78 years, that differed according to the site of presentation as shown in the table. Median age was 58 years with male:female ratio of 1.4:1. In another study, median age was 56.7 and male:female ratio was 1.5:1 1 .

The most common site of presentation was oral cavity $(26 \% ; n=10)$, followed by parotid and thyroid $(18 \%$ each; $n=7)$, eye $(12 \%, n=5)$, maxilla $(8 \% ; n=3)$, paranasal sinuses $(8 \% ; \mathrm{n}-=3)$ cheek $(8 \%, \mathrm{n}=3)$, and nasal cavity $(2 \%, \mathrm{n}=1)$. In one study, the sites involved were: Waldeyer's ring-103 patients (tonsil-60, nasopharynx-25, base of tongue-18), and extralymphatic sites - 53 patients (salivary gland - 20, paranasal sinus - 20, oral cavity - 10, and laryn $x-3)^{17}$. In another study, the most frequent primary site was the tonsil (28 cases), followed by oral cavity, parotid gland, orbit and other sites ${ }^{18}$. We have not included the patients of Waldeyer's ring in our study as it is considered to be a nodal disease nowadays.

Most of the patients presented in early stage. $41 \%$ $(n=16)$ cases were in stage $I, 43 \%(n=17)$ in stage II, $3 \%(\mathrm{n}=1)$ in stage III, and $13 \%(\mathrm{n}=5)$ were in stage IV. These results are in accordance with those reported by Conley et al. ${ }^{19}$, Jacobs and Hoppe ${ }^{17}$, and Wong et $\mathrm{aL}^{20}$ from the United States.

Most of the patients were of low risk (67\%; n=26), followed by intermediate $(23 \%$; $n=9)$, and high risk $(10 \% ; n=4)$. In contrary, in another study, $72 \%$ of the specimens were intermediate-, 14\% were high-, and $12 \%$ were low-grade malignancies ${ }^{21}$. This depicts more patients in our study belonged to low-risk category, that could be explained by a better performance status or lower LDH levels in our patients as compared to other studies.

Chemotherapy alone was given in $36 \%(n=14)$ of the patients, and chemotherapy along with radiotherapy in $51 \%(n=20)$ of the patients. Remaining patients were either lost to follow up or untreated. Most of the early stage patients were treated with both the modalities of treatment. In stage I, one patient was given R-CEOP, one patient COP, and all others were given CHOP. In stage II, 2 patients were given RCHOP, one patient R-CEOP, and remaining were given $\mathrm{CHOP}$, one with triple IT. In stage III and stage $\mathrm{IV}$, all patients were given $\mathrm{CHOP}$.

Traditionally, Stage I and II patients have been treated with radiotherapy alone, but the initial treatment of this type of localized disease is yet a matter of controversy. Some authors have stated that combined therapy was significantly superior to radiotherapy alone in Stage I and II patients, with respect to overall survival ${ }^{22}$, disease-free survival ${ }^{22}$, relapse-free survival ${ }^{23}$ and the relapse rate ${ }^{23}$. Teshima et $\mathrm{al}^{24}$ demonstrated the superiority of combined therapy over radiotherapy alone for Stage II patients and the ineffectiveness of chemotherapy for Stage I patients. On the other hand, Cabanillas et $\mathrm{al}^{25}$ found that chemotherapy alone was effective for patients with Stage I and II disease, although Cabanillas recommended radiotherapy following the chemotherapy in Stage II patients with bulky disease. In this study, stage I and stage II patients had a better prognosis and overall survival. This is in accordance with another study in which Stage 1 and II patients had a good prognosis and advanced stage patients had a poor prognosis ${ }^{16}$.

According to site, the best median overall survival was seen with parotid $(27 \mathrm{~m})$, paranasal sinus $(26 \mathrm{~m})$, and oral cavity $(23 \mathrm{~m})$, followed by thyroid $(18 \mathrm{~m})$ nasal cavity $(17 \mathrm{~m})$, maxilla $(11 \mathrm{~m})$, eye $(8 \mathrm{~m})$, and cheek $(7 \mathrm{~m})$. In a study of 156 cases of extranodal head and neck lymphoma, Jacobs and Hoppe ${ }^{20}$ reported that lymphoma of the paranasal sinuses had the poorest prognosis (5-year survival, 12\%), which was contrary to our study.

\section{REFERENCES}

[1] Boring CC, Squires TS, Tong T (1993). Cancer statistics. CA Cancer J Clin 43: http://dx.doi.org/10.3322/canjclin.43.1.7

[2] Urquhart A, Berg R (2001). Hodgkin's and non-Hodgkin's lymphoma of the head and neck. Laryngoscope 111: 15651569. http://dx.doi.org/10.1097/00005537-200109000-00013

[3] Zapater E, Baga' n JV, Campos A, Armengot M, Abril V, Basterra J (1996). Non-Hodgkin's lymphoma of the head and neck in association with HIV infection. Ann Otolaryngol 
Chir Cervicofac 113: 69-72.

[4] Vega F, Lin P, Medeiros J (2005). Extranodal lymphomas of the head and neck. Ann Diagn Pathol 9: 340-350. http://dx.doi.org/10.1016/j.anndiagpath.2005.09.020

[5] Harris NL, Jaffe ES, Stein H, Isaacson PG (1994). A revised European-American classification of lymphoid neoplasm: a proposal from the International Lymphoma Study Group. Blood 84: 1361-1392.

[6] Nathu RM, Mendenhall NP, Almasri NM, Lyunch JW (1999). Non-Hodgkin's lymphoma of the head and neck: a 30-year experience at the University of Florida. Head Neck 21: 247-254. http://dx.doi.org/10.1002/(sici)10970347(199905)21:3\%3C247::aid-hed10\%3E3.0.co;2-6

[7] Talmon Y, Gilbey P, Falah R, Samet A, Cohen H, Khoury J (2007). Primary B cell lymphoma of the tongue. IMAJ 9: $755-756$.

[8] Jovanovic MB (2008). An exophytic localized lymphoma of the tongue base. Otolaryngol Head Neck Surg 139: 468-469. http://dx.doi.org/10.1016/j.otohns.2008.05.011

[9] Feinberg SM, Ou SH, Gu M, Shibuya TY (2007). Burkitt's lymphoma of the base of the tongue: a case report and review of the literature. Ear Nose Throat J 86: 356-360.

[10] Levine AM (1992). Acquired-immunodeficiency syndromerelated lymphoma. Blood 80: 8-20.

[11] Weber A, Rahemtullah A, Ferry JA (2003). Hodgkin and nonHodgkin lymphoma of the head and neck: clinical, pathologic, and imaging evaluation. Neuroimaging Clin $\mathrm{N}$ Am 13: 371-392. http://dx.doi.org/10.1016/s10525149(03)00039-x

[12] Lima I, Carneiro AS, Amorim CA, Santiago MB (2008). Hodgkin lymphoma as a complication of primary Sjo" gren's syndrome. Mod Rheumatol 18: 200-202. http://dx.doi.org/10.1007/s10165-008-0030-7

[13] Coltrera MD (1999). Primary T-cell lymphoma of the

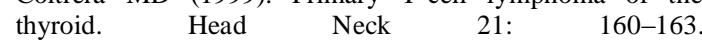
http://dx.doi.org/10.1002/(sici)10970347(199903)21:2\%3C160::aid-hed10\%3E3.0.co;2-f

[14] Cheung MM, Chan JK, Lau WH et al (1998). Primary nonHodgkin's lymphoma of the nose and nasopharynx: clinical features, tumor immunophenotype, and treatment outcome in 113 patients. J Clin Oncol 16: 70-77.

[15] Cuadra-Garci'a I, Proulx GM, Wu CL et al (1999). Sinonasal lymphoma: a clinicopathologic analysis of 58 cases from the Massachusetts General Hospital. Am J Surg Pathol 23: 13561369.

[16] Shima $\mathrm{N}^{1}$, Kobashi Y, Tsutsui K et al. Extranodal nonHodgkin's lymphoma of head and neck. A clinicopathologic study in the Kyoto-Nara area of Japan. Cancer. 1990 Sep 15;66(6):1190-7 http://dx.doi.org/10.1002/10970142(19900915)66:6\%3C1190::aidcncr2820660619\%3E3.0.co;2-u

[17] Jacobs C, Hoppe RT. Non-Hodgkin's lymphomas of head and neck extranodal sites. Inr J Radiat Oncol Biol Phys 1985; $11: 357-364$ http://dx.doi.org/10.1016/0360-3016(85)90158-0

[18] Economopoulos T, Asprou N, Stathakis N, Fountzilas G, Pavlidis N, Papaspyrou S, Dervenoulas J, Belia M, Papageorgiou E, Theoharis D, et al Primary Extranodal NonHodgkin's Lymphoma of the Head and Neck..Oncology. 1992;49(6):484-8. http://dx.doi.org/10.1159/000227097

[19] Conley SF, Staszak C, Clamon GH, Maves MD. NonHodgkin's lymphoma of the head and neck: The University of Iowa experience. Laryngoscope 1987; 97:291-300. http://dx.doi.org/10.1288/00005537-198703000-00007
[20] Wong DS, Fuller LM, Butler JJ, Shullenberger CC. Extranodal- non-Hodgkin's lymphomas of the head and neck. AJR 1975: 123:471- 481. 6 http://dx.doi.org/10.2214/ajr.123.3.471

[21] Etemad-Moghadam S, Tirgary F, Keshavarz S, Alaeddini M. Head and neck non-Hodgkin's lymphoma: a 20-year demographic study of 381 cases. Int J Oral Maxillofac Surg. $2010 \quad$ Sep;39(9):869-72. doi: 10.1016/j.ijom.2010.03.029. Epub 2010 Jun 9. http://dx.doi.org/10.1016/j.ijom.2010.03.029

[22] Liang R, Ng RP, Todd D, Choy D, Khoo RKK, Ho FCS. Man- agement of stage 1-11 diffuse aggressive nonHodgkink lymphoma of the Waldeyer's ring: Combined modality therapy versus radiotherapy alone. Hematol Oncol 1987; 5:223-230. http://dx.doi.org/10.1002/hon.2900050309

[23] Nissen NI, Ersboll J, Hansen HS et al. A randomized study of radiotherapy versus radiotherapy plus chemotherapy in stage 1-11 non- Hodgkin's lymphomas. Cancer 1983; 52: 1-7. http://dx.doi.org/10.1002/10970142(19830701)52:1\%3C1::aidcncr2820520102\%3E3.0.co;2-m

[24] Teshima T, Chatani M, Hata K et al. Radiation therapy for pri- mary non-Hodgkin's lymphoma of the head and neck in stage 1-11, Strahlenther Onkol 1986; 162:478-483.

[25] Cabanillas F, Bodey GP, Freireich EJ. Management with chemotherapy only of stage I and II malignant lymphoma of aggressive histologic types. Cancer 1980; 46:2356-2359 http://dx.doi.org/10.1002/1097-

0142(19801201)46:11\%3C2356::aidcncr2820461107\%3E3.0.co;2-x 


\begin{tabular}{|c|c|c|c|c|c|c|c|c|c|c|c|c|}
\hline \multirow[t]{2}{*}{ SITE } & \multirow{2}{*}{$\begin{array}{l}\text { NO. OF } \\
\text { CASES }\end{array}$} & \multicolumn{3}{|c|}{ STAGE } & \multicolumn{2}{|c|}{ IPI } & \multirow[b]{2}{*}{$\begin{array}{l}\text { DLBCL } \\
\text { FL PBL }\end{array}$} & \multicolumn{3}{|c|}{ HISTOLOGY } & \multirow{2}{*}{$\begin{array}{l}\text { MEDIAN } \\
\text { AGE } \\
\text { (RANGE) }\end{array}$} & \multirow{2}{*}{$\begin{array}{l}\text { MEDIAN } \\
\text { OS } \\
\text { (RANGE) }\end{array}$} \\
\hline & & $\begin{array}{l}\text { I } \\
\text { III }\end{array}$ & & & $\begin{array}{l}\text { RISI } \\
\text { LOV } \\
\text { HIG }\end{array}$ & NT. & & & & & & \\
\hline $\begin{array}{l}\text { ORAL CAVITY } \\
\text { Palate } \\
\text { Buccal mucosa } \\
\text { Gingiva } \\
\text { Lip } \\
\text { Tongue }\end{array}$ & $\begin{array}{l}10 \\
3 \\
1 \\
1 \\
1 \\
4\end{array}$ & $\begin{array}{l}6 \\
1\end{array}$ & 3 & 0 & $2^{6}$ & 2 & $4^{3} \quad 0$ & 0 & 0 & 0 & $\begin{array}{c}43 \\
(26-68)\end{array}$ & $\begin{array}{c}23 \\
(8-33)\end{array}$ \\
\hline NASAL CAVITY & 1 & $\begin{array}{l}1 \\
0 \\
\end{array}$ & 0 & 0 & $0^{1}$ & 0 & 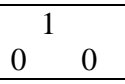 & 0 & 0 & 0 & 18 & 17 \\
\hline $\begin{array}{l}\text { PARANASAL } \\
\text { SINUS } \\
\text { Frontal } \\
\text { Fronto-ethmoid } \\
\text { Ethmoid- } \\
\text { maxillary-sphenoid }\end{array}$ & $\begin{array}{l}3 \\
1 \\
1 \\
1\end{array}$ & $\begin{array}{l}3 \\
0\end{array}$ & 0 & 0 & $0^{3}$ & 0 & $0^{2} 1$ & 0 & 0 & 0 & $\begin{array}{c}41 \\
(40-42)\end{array}$ & $\begin{array}{c}26 \\
(1-51)\end{array}$ \\
\hline MAXILLA & 3 & $\begin{array}{l}1 \\
0\end{array}$ & 2 & 0 & $0^{2}$ & 1 & $0^{3} 0$ & 0 & 0 & 0 & $\begin{array}{c}56 \\
(55-72)\end{array}$ & $\begin{array}{c}11 \\
(2-35)\end{array}$ \\
\hline CHEEK & 3 & $\begin{array}{l}2 \\
0\end{array}$ & 1 & 0 & $0^{2}$ & 1 & $0^{3} 0$ & 0 & 0 & 0 & $\begin{array}{c}51 \\
(42-58) \\
\end{array}$ & $\begin{array}{c}7 \\
(1-10)\end{array}$ \\
\hline EYE & 5 & $\begin{array}{l}1 \\
2 \\
\end{array}$ & 2 & 0 & $1^{3}$ & 1 & \begin{tabular}{ll}
\multicolumn{2}{c}{0} \\
0 & 0 \\
\end{tabular} & 2 & 1 & 2 & $\begin{array}{c}64 \\
(40-75)\end{array}$ & $\begin{array}{c}8 \\
(1-15)\end{array}$ \\
\hline PAROTID & 7 & $\begin{array}{l}2 \\
1 \\
\end{array}$ & 3 & 1 & $0^{6}$ & 1 & $0^{2} \quad 0$ & 1 & 0 & 0 & $\begin{array}{c}51 \\
(42-78)\end{array}$ & $\begin{array}{c}27 \\
(7-54)\end{array}$ \\
\hline THYROID & 7 & $\begin{array}{l}0 \\
1 \\
\end{array}$ & 6 & 0 & $1^{3}$ & 3 & $\begin{array}{ll} & 7 \\
0 & 0 \\
\end{array}$ & 0 & 0 & 0 & $\begin{array}{c}68 \\
(50-72) \\
\end{array}$ & $\begin{array}{c}18 \\
(8-32) \\
\end{array}$ \\
\hline TOTAL & 39 & $\begin{array}{l}16 \\
5\end{array}$ & 17 & 1 & $4^{26}$ & 9 & $4^{2} \quad 1$ & 3 & 1 & 2 & & \\
\hline
\end{tabular}

TABLE 1. Depicts the baseline characteristics of the patients and distribution based on the site, age, stage IPI risk, histology and median overall survival (OS) according to site.

\begin{tabular}{|c|c|c|c|c|c|}
\hline 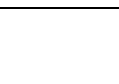 & Chemotherapy & $\begin{array}{l}\text { Chemotherapy + } \\
\text { Radiotherapy }\end{array}$ & Untreated & Unknown & $\begin{array}{l}\text { OVERALL } \\
\text { SURVIVAL }\end{array}$ \\
\hline I & 4 & 8 & 0 & 1 & $\begin{array}{c}28 \\
(2-120)\end{array}$ \\
\hline II & 5 & 9 & 0 & 2 & $\begin{array}{c}11 \\
(2-45)\end{array}$ \\
\hline III & 2 & 1 & 0 & 1 & $\begin{array}{c}7 \\
(1-16)\end{array}$ \\
\hline IV & 3 & 2 & 1 & 0 & $\begin{array}{c}3 \\
(1-14) \\
\end{array}$ \\
\hline TOTAL & 14 & 20 & 1 & 4 & \\
\hline
\end{tabular}

TABLE 2. Depicts the treatment modality used and the overall survival according to the stage of the disease.

\begin{tabular}{|l|l|l|l|l|l|}
\hline & Nobuko et al & $\begin{array}{l}\text { Economopoulos et } \\
\text { al }\end{array}$ & $\begin{array}{l}\text { Economopoulos et } \\
\text { al (2) }\end{array}$ & Joel et al & Our study \\
\hline Median age & 60.5 years & 55 years & 56 years & 62.5 years & 56.7 years \\
\hline M/C site & Oral cavity & Oral cavity & Oral cavity & Parotid & Oral cavity \\
\hline M/C stage & Stage I/II & Stage I/II & Stage I/II & - & Stage I/II \\
\hline M/C risk category & $\begin{array}{l}\text { Intermediate } \\
(75 \%)\end{array}$ & - & $\begin{array}{l}\text { Intermediate } \\
(62.9 \%)\end{array}$ & - & $\begin{array}{l}\text { Low } \\
(67 \%)\end{array}$ \\
\hline $\begin{array}{l}\text { Best survival } \\
\text { (based on stage) }\end{array}$ & Stage I & Stage I & - & Stage I \\
\hline $\begin{array}{l}\text { Best Survival } \\
\text { (based on site) }\end{array}$ & $\begin{array}{l}\text { Paranasal } \\
\text { sinus/thyroid/larynx }\end{array}$ & - & - & - & $\begin{array}{l}\text { Parotid/paranasal } \\
\text { sinus }\end{array}$ \\
\hline
\end{tabular}

Table 3. Comparing our study with previous studies. 